\title{
History of studying the Fedorova-Pana Layered Complex and associated Cu-Ni-PGE mineralization, Kola Peninsula, Russia
}

\author{
T. V. Rundkvist, P. V. Pripachkin*, N. Yu. Groshev \\ Geological Institute, Kola Science Centre, Russian Academy of Sciences (GI KSC RAS) 184209 Apatity, Russia \\ *Corresponding author e-mail: pripaul@rambler.ru \\ Summary The intrusive layered complex of mafic and ultramafic rocks on the Fedorova and Pana \\ Tundras (Tundra - a mountain in the Sami language) in the central part of the Kola Peninsula has been \\ studied since the late 19th and early 20th centuries. Searches for $\mathrm{Cu}-\mathrm{Ni}$ ores were carried out in the 30s- \\ 80 s of the XX century, but no rich ores were found. Prospecting for platinum group elements (PGE) \\ mineralization started at the end of the 20th century and led to the discovery of four PGE deposits and \\ numerous ore occurrences. Large areas of the Fedorova-Pana Layered Complex remain poorly studied.
}

\section{Prospecting for $\mathrm{Cu}-\mathrm{Ni}$ ore in the Fedorova-Pana Layered Complex}

Geographical and geological survey of the Kola Peninsula was launched by expeditions of N. Kudryavtsev (1881), Ch. Rabot (1884), Finnish scientists A. Kihlman, W. Ramsay and A. Petrelius (1887-1889), topographers B.A. Rippas and P.B. Rippas (1890s) in the second half of the 19th century. In 1898 P.B. Rippas led an expedition on the south of the Kola Peninsula to the Varzuga River basin and the Fedorova-Pana Tundras area. Characteristic gabbros of dark, almost black colour, in some places influencing the magnetic needle, were discovered in the Pana Tundras (Rippas, 1899).

In 1927, an expedition of the USSR Academy of Sciences led by geologist N.N. Gutkova obtained the first information about intrusive rocks of the Fedorova-Pana Tundras. A geological survey at a scale of 1: 1000000 was carried out on the Fedorova-Pana Tundras in 1931-1932.

In 1933, an expedition of the USSR Academy of Sciences headed by F.P. Kharchenko carried out a geological survey at a scale of 1: 50000 and small mining operations on the Fedorova Tundra area. Norites with sulfide dissemination were found. Prospecting for $\mathrm{Cu}-\mathrm{Ni}$ ores on the Fedorova-Pana Tundras started in 1934-1941. The Severonikel plant was constructed during these years near Monchegorsk. It was established to process the rich $\mathrm{Cu}-\mathrm{Ni}$ ore from vertical sulfide veins of the Monchegorsk Layered Complex. In addition to the rich ores of Monchegorsk, the Fedorova-Pana ore was assumed to increase the $\mathrm{Cu}-\mathrm{Ni}$ ore reserves in the central part of the Kola Peninsula.

In 1939, D.V. Shifrin discovered Pt and Pd in a total amount of 0.5 to $2 \mathrm{ppm}$ in individual samples from sulfide-bearing gabbronorites of the Fedorova intrusion. However, the data raised no interest in those years. The reserves of $\mathrm{Cu}-\mathrm{Ni}$ ores in the Fedorova intrusion were insufficient for industrial development, thus the work was pretermitted.

In the 1940s-70s, the study of the Fedorova-Pana intrusion geology and the search for rich $\mathrm{Cu}-\mathrm{Ni}$ ores were continued. In 1960, the entire territory of the Fedorova-Pana intrusion was covered with aeromagnetic and airborne gamma surveys at a scale of 1: 50000. Geophysical work and numerous drilling works were carried out. S.M. Chikhachev discovered poor sulfide dissemination in the "banded complex" (the Lower Layered Horizon) of the Pana Tundras Ridge in 1961. The find preconditioned complex geological and geophysical works organized by the North-Western Geological Department of the USSR Ministry of Geology. The works were carried out by V.V. Proskuryakov in 1961-1964. A number of sulfide occurrences 
were established in the Lower Layered Horizon of the West Pana intrusion. Petrographic and geochemical studies were held in the Geological Institute (E.K. Kozlov, A.Yu. Odinets, G.N. Staritsina, S.M. Chikhachev, etc.). These studies provided the conclusion that there was no rich $\mathrm{Cu}-\mathrm{Ni}$ ore in the Fedorova-Pana Tundras.

In 1979, M.K. Radchenko and V.S. Dokuchaeva found elevated PGE content (up to $4-$ $5 \mathrm{ppm}$ ) in samples with sulfide $\mathrm{Cu}-\mathrm{Ni}$ mineralization from the eastern flank of the Fedorova intrusion (Pakhkvaraka, Last'yavr) and from the Lower Layered Horizon of the West Pana intrusion. Yu.N. Neradovsky was the first to find merenskyite, a rare telluride of palladium, in these ores.

\section{Prospecting for PGE in the Fedorova-Pana Layered Complex}

In the 80 s of the 20 th century, there was a change in the prospecting trend - from $\mathrm{Cu}-\mathrm{Ni}$ to PGE mineralization. A detailed geological and petrological analysis of the data was carried out by GI KSC RAS in the mid-1980s (V.S. Dokuchaeva, N.N. Veselovsky, etc.). The analysis showed a great similarity between the rocks of the Fedorova-Pana Complex and the Stillwater Complex in the USA. GI KSC RAS has been studying the complex ores (Pd, Pt, Rh, $\mathrm{Au}, \mathrm{Ag}, \mathrm{Cu}, \mathrm{Ni}, \mathrm{Co}$ ) of the Fedorova-Pana Complex since 1986. It was found that sulfide $\mathrm{Cu}$-Ni-PGE mineralization was associated with two horizons of finely layered rocks in the West Pana intrusion, the lower and upper.

Four bore holes were drilled by GI KSC RAS in the Lower Layered Horizon at the Suleipakhk area in 1989. For the first time, the aim of drilling on the Fedorova-Pana Tundras was to find PGE rather than $\mathrm{Ni}$ and $\mathrm{Cu}$. The bore holes crossed four intervals with complex PGE mineralization. The analysis of the obtained materials allowed Academician F.P. Mitrofanov as a director of GI KSC RAS to suggest the existence of the Kola platinummetal province in 1989.

Geological mapping of the West Pana intrusion was followed up by a group of GI KSC RAS in 1990. A.U. Korchagin, L.A. Vinogradov, E.M. Bakushkin, Yu.L. Voitekhovsky, A.I. Mednikov, S.M. Karpov and other scientists participated in this work. It was carried out within the Lower Layered Horizon in the West Pana intrusion. In result, the North PGE Reef was traced for more than $11 \mathrm{~km}$.

GI KSC RAS initiated the creation of a small innovative enterprise JSC "Pana" in 1991. F.P. Mitrofanov became the Chairman of the Board of Directors. A.L. Gritsay was General Director of the small enterprise in 1992-1999, and A.U. Korchagin has been General Director since 2000. In the same year A.U. Korchagin as senior geologist of the JSC "Pana" conducted a detailed study of the North PGE Reef structure at the Eastern and Central Kievey areas that included tracing the reef with 30-60 m deep drill holes.

Drilling and blasting works were carried out in the East Kievey area, and 1400 tons of complex platinum-metal ore as a technological sample were prepared in a pilot pit. From 1993 to 1999 prospecting works in the Fedorova-Pana Tundras were implemented jointly with and with the financial support from the "BHP Minerals" company. During these years, geological surveys at a scale of 1: 5000 and sampling for PGE have been carried out in almost all exposed areas of the West Pana and Fedorova intrusions by, in particular, A.U. Korchagin, S.M. Karpov, V.V. Subbotin, A.S. Osokin, A.N. Kulakov and A.E. Borisov. In 1993, a chain of high PGE boulders was traced in the South Suleipakhk area. Currently, these boulders are well-known to be fragments of the South PGE Reef in the Upper Layered Horizon of the West Pana intrusion.

The petrology of the West Pana intrusion was studied by M.I. Dubrovsky, V.V. Borisova, R.M. Latypov (GI KSC RAS). R.M. Latypov studied the structure and genesis of the Lower Layered Horizon of the West Pana intrusion at the Maryok area (Latypov et al., 1999). During fieldworks within the Maryok and South Kamennik areas of the West Pana 
intrusion in 1995, R.M. Latypov and P.V. Pripachkin provided a detailed mapping and sampling of profiles through the Lower Layered Horizon and Upper Layered Horizon, including bodies of magnetite gabbro. The study of these materials became the basis for constructing petrological models of formation of layered horizons and magnetite gabbro bodies (Latypov, Chistyakova, 2000).

The mineralogy of ore occurrences was investigated by N.L. Balabonin, V.V. Subbotin, Yu.N. Neradovsky, D.A. Gabov and E.E. Savchenko; more than fifty minerals and mineral phases of platinum group metals have been identified, including mitrofanovite $\mathrm{Pt}_{3} \mathrm{Te}_{4}$ and panskyite $\mathrm{Pd}_{9} \mathrm{Ag}_{2} \mathrm{~Pb}_{2} \mathrm{~S}_{4}$ as two new mineral species (Subbotin et al., 2012a; Subbotin et al., 2012b; Subbotin et al., 2019; Vymazalová et al., 2020).

Until recently, the East Pana intrusion used to be considered non-sulfide-bearing and unpromising in terms of PGE mineralization. In 1995-1998 JSC "Pana" prospected several sites of the East Pana Intrusion for PGE mineralization. Geologists S.M. Karpov, V.V. Subbotin and A.N. Kulakov discovered ore occurrences with an industrial PGE grade here.

"Barrick Gold Corporation" has been interested in PGE ore occurrences in the Fedorova-Pana Tundras since 2001. This provided financial opportunities for large-scale prospecting, appraisal and exploration work in cooperation with "Barrick Gold Corporation" (E. Nozdrya, V. Clemens, V. Komar and others). The main ore body of the Fedorova Tundra was traced to a depth of $300 \mathrm{~m}$ from the surface; its reserves were preliminarily estimated in 2001-2003 as a result of cooperation of JSC "Pana" and "Barrick Gold Corporation". In 20042005, detailed exploration was carried out in the contour of the boundaries of the proposed quarry.

In 2001, JSC "Pana" provided a detailed geological survey of the surface at a scale of 1: 5000 and drilling of 26 bore holes in the North PGE Reef of the West Pana intrusion, from the Maryok to the Central Kievey areas. This study confirmed the continuity of the North PGE Reef and allowed detecting objects of greatest interest. Further work on this territory was carried out by JSC "Pana" with the financial support of the "Ural Minerals Investment Company". The main ore body was preliminarily explored with an estimate of reserves to a depth of $400 \mathrm{~m}$ from the surface (Kievey deposit).

In 2002-2005, JSC "Pana" (A.U. Korchagin, V.P. Pavlov, S.M. Karpov, P.V. Pripachkin, S.V. Ivanov, V. Lobanov, etc.) together with "Kola Mining and Geological Company" (M. Vard, O. Kazanov, A. Kalinin, P. Dubchak, S. Pevzner, V.S. Voitekhovich, etc.) representing the "Bema Gold" company in Russia performed prospecting and economic evaluation of ore occurrences in the East Pana intrusion (Churozerskiy, South-West Peshempakhk, PredgorniyKuksha, East Chuarvy areas). Further works at this facility were continued by the "Kola Mining and Geological Company". As a result, the East Chuarvy PGE deposit was put on the state balance sheet in 2008 .

Scientific research of the Fedorova-Pana Layered Complex was devoted to isotope dating of different magmatic phases (T.B. Bayanova and others) and to the construction of petrological models of individual intrusions of the complex (M.I. Dubrovskiy, N.Yu. Groshev). Several lines of evidence show that the intrusions were crystallized out of its stratigraphic sequence (Dubrovskiy and Rundkvist, 2008; Groshev and Karykowski, 2019; Groshev et al., 2019).

The "Fedorovo Resources", a representative of the "Barrick Gold Corporation" in Russia, and JSC "Pana" provided additional exploration works in 2006. The management of "Barrick Gold Corporation" decided to mine the Fedorova Tundra deposit as an open pit. Extensive drilling operations, more than $100 \mathrm{~km}$ of drill core, were carried out at the Fedorova Tundra in 2007-2008. The Fedorova Tundra deposit and the Kievey deposit were put on the state balance sheet in 2008-2009. JSC "Pana" continued prospecting and economic evaluation 
at the North Kamennik area of the West Pana intrusion. In result of these works, a new PGE deposit was identified and approved by the State Reserves Committee in 2015 (Korchagin et al., 2016).

\section{Conclusion}

Thus, a hundred years after obtaining first data on the Fedorova-Pana Tundras and 80 years after the first mentioning of PGE-enriched rocks, four deposits were discovered, all awaiting commercial development. These deposits are the Fedorova Tundra (Fedorovotudrovskoye), Kievey, North Kamennik and East Chuarvy. The potential for new PGE discoveries is high at the Fedorova-Pana Tundras. The most promising target is the North PGE Reef. It is about 15 $\mathrm{km}$ long on the surface and cut by two bore holes at a depth of $400 \mathrm{~m}$. Studying this object all along its length and measuring its size at depth are interesting challenges for further research.

\section{Acknowledgements}

The research was supported by the Ministry of Science and Higher Education of the Russian Federation (project 0226-2019-0053).

\section{References:}

Groshev NY, Karykowski BT (2019) The Main Anorthosite Layer of the West Pana Intrusion, Kola Region: Geology and U-Pb Age Dating. Minerals 9:71. https://doi.org/10.3390/min9020071

Groshev NY, Rundkvist TV, Karykowski BT, et al. (2019) Low-Sulfide Platinum-Palladium Deposits of the Paleoproterozoic Fedorova-Pana Layered Complex, Kola Region, Russia. Minerals 9:764 https://doi.org/10.3390/min9120764

Dubrovskiy MI, Rundkvist TV (2008) Petrology of the Early Proterozoic platinum-bearing Fedorova Tundra massif (Kola Peninsula). Zap RMO CXXXVII:20-33. In Russian.

Korchagin AU, Goncharov YV, Subbotin VV, et al (2016) Geology and composition of the ores of the lowsulfide North Kamennik PGE deposit in the West-Pana intrusion. Ores Met 1:42-51. In Russian.

Latypov RM, Mitrofanov FP, Alapieti TT, Halkoaho TA (1999) Petrology of the Lower Layered Horizon of the Western Pansky Tundra intrusion, Kola Peninsula. Petrology V 7, № 5, pp 482-508.

Latypov RM, Chistyakova SYu (2000) The mechanism of differentiation of the layered intrusion of the West Pansky tundra. Kola Science Centre RAS, Apatity, 315 p. In Russian.

Rippas PB (1899) The Kola Expedition of 1898: Preliminary Report. In: Izv. Imp. Russian geographic society. V 35, Issue 3. pp 292-312, 1 p. maps. In Russian.

Subbotin VV, Korchagin AU, Savchenko EE (2012a) Platinum mineralization of the Fedorova-Pana ore cluster: types of mineralization, mineral composition, features of genesis. In: Bulletin of KSC RAS. №1, pp 55-66. In Russian.

Subbotin VV, Korchagin AU, Gabov DA et al. (2012b) Localization and composition of low-sulfide platinummetal mineralization in the West Pana massif. In: Trudy FNS. Publishing House K\&M, Apatity. pp 302-307. In Russian

Subbotin VV, Vymazalová A, Laufek F et al. (2019) Mitrofanovite, $\mathrm{Pt}_{3} \mathrm{Te}_{4}$, a new mineral from the East Chuarvy deposit, Fedorovo-Pana intrusion, Kola Peninsula, Russia. Mineral Mag 83:523-530

Vymazalová A, Subbotin VV, Laufek F et al. (2020) Panskyite, $\mathrm{Pd}_{9} \mathrm{Ag}_{2} \mathrm{~Pb}_{2} \mathrm{~S}_{4}$, a new platinum group mineral from the Southern Kievey ore occurrence of the Fedorova-Pana layered intrusion, Kola Peninsula, Russia Mineral Mag 1-11. https://doi.org/10.1180/mgm.2020.100 